\title{
Limits of Conversion: Caste, Labor, and the Question of Emancipation in Colonial Panjab
}

\section{NAVYUG GILL}

This article explores the contradictory history of lower castes converting out of Hinduism yet not out of lowliness or casteism in early twentieth-century Panjab. It begins by contextualizing what B. R. Ambedkar's undelivered 1936 Lahore speech on annihilating caste might have meant to an audience of largely landless agricultural laborers. Next it examines the changing constellation of caste names and occupational designations for these groups amid the emergence of the Ad Dharm movement and its struggle to impart equality, dignity, and community to Panjabi Dalits. To situate this new sense of identity in the context of actual labor practices, the article then analyzes the fraught relationship between landholding cultivators and landless laborers working side-by-side while continuing to be separate and unequal. That a large proportion of lower castes could adopt religions other than Hinduism or even start their own and yet remain excluded and exploited reveals the limits of a politics centered on conversion, as well as a different horizon for emancipation.

Keywords: Ad Dharm, agrarian history, B. R. Ambedkar, caste conflict, census categories, Dalit politics, Karl Marx, menial laborers, religious conversion, rural Panjab

$\mathrm{O}$ Necember 12, 1935, Bhimrao Ramji Ambedkar received an invitation from Sant Ram, the secretary of the Jat-Pat Todak Mandal (Association for the Breaking of Caste), to address its annual conference the following spring in Lahore. No one had studied the problem of caste as deeply as Ambedkar, wrote Ram, adding that the "independent Harijans of Punjab are very much desirous to meet you and discuss with you their plans" (Ambedkar [1936] 1979, 27). Ambedkar reluctantly agreed, but after obtaining a copy of his speech, the Mandal leadership became uneasy with some of its content and requested he make certain changes. In particular, they expressed surprised objection to passages where Ambedkar denounced the morality and sanctity of the Hindu religion and scripture, and declared his intention to ultimately leave its fold. Ambedkar resolutely refused, stating he would "not alter a comma" and accused the Mandal of duplicity before withdrawing from the conference, which was later cancelled altogether (34-35). On returning to Bombay with nearly a thousand printed copies of the speech, he decided to distribute it on his own under the title Annihilation of Caste. It sold out quickly, provoking two rebuttals from Mohandas Karamchand Gandhi, to which Ambedkar issued a lengthy reply in 1937. Since then it has been considered not only one of

Navyug Gill (gilln2@wpunj.edu) is Assistant Professor in the Department of History at William Paterson University. 
Ambedkar's most famous texts, but also a radical and penetrating intervention into the nature of the problem of caste. ${ }^{1}$

The question Ambedkar addresses in his undelivered speech is how to understand, confront, and abolish the peculiar institution of hereditary hierarchy in Indian society. Untouchability is not to be overcome by mere shifts in attitude, nor is it sufficient to rely on straightforward political or economic remedies. Of activists in the Indian National Congress, he asks: "Are you fit for political power even though you do not allow a large class of your own countrymen like the untouchables to use public schools?" Similarly, of socialists who insist on the primacy of material relations, he asks: "Can it be said that the proletariat of India, poor as it is, recognize no distinctions except that of the rich and the poor?" $(41,46)$. According to Ambedkar, the presumed unity of citizenship or class is undercut by a more intractable ideology of caste separation. This phenomenon is unique to India because it is not only a division of labor, prevalent all over the world, but "also a division of labourers" based on fixity, graded inequality, and predestination (47). That is why efforts at inter-caste dining and marriage are ineffective and unrealizable, however laudable. The deeper problem, argues Ambedkar, is that such a hierarchy is sanctioned and indeed mandated by Hinduism through its sacred texts, known as the Shastras. Individual Hindus observe caste not because they are "inhuman or wrongheaded"; rather, they do so "because they are deeply religious." As a result, Ambedkar declares, "what is wrong is their religion, which has inculcated this notion of caste" (68). The solution is as succinct as it is searing: "the real remedy" is to "discard the authority of the Shastras and destroy the religion of the Shastras" (78). Only when the legitimacy of hereditary separation is overturned will there emerge the possibility of a genuinely inclusive, united, and equal society worthy of independence.

What if Ambedkar had delivered this speech in Lahore in 1936? Given the social and economic polarities of Panjabi society, his diagnosis and remedy to the sickness of caste seems strikingly incongruent with the composition of his intended audience. ${ }^{2}$ According to the 1931 census, over 87 percent of the population lived in villages, of which Hindus made up less than 30 percent, while the bulk of the remainder was 53 percent Muslim and 15 percent Sikh. ${ }^{3}$ More significantly, a few years earlier a group of activists succeeded in registering a separate religion explicitly for lower castes called Ad Dharm or "Original Faith," drawing on the teachings of Bhagats Kabir (c. 1398-1448), Namdev

\footnotetext{
${ }^{1}$ In an endorsement on the front flap of a recently published annotated edition of this text, the writer and activist Anand Teltumbde states: "What Communist Manifesto is to the capitalist world, Annihilation of Caste is to caste India." See Ambedkar (2014).

${ }^{2}$ In this article, I transliterate the word यैस्माप्व or بنجاب as “Panjab," since there is neither a "u" letter equivalent in the vernacular Gurmukhi or Shahmukhi spelling, nor an "uu" sound in the pronunciation of the word. Although "Punjab" is the more common rendering, with notable exceptions such as Panjab University in Chandigarh, it is a persistent colonial-era mis-transliteration.

${ }^{3}$ According to the 1931 census, Panjab had a total population of $28,490,857$, of which $23,580,852$ (82.8 percent) were under direct British rule and 4,910,005 (17.2 percent) under seventeen different subordinate native principalities. The overwhelming majority lived in the countryside rather than cities: 87.6 percent rural to 12.4 percent urban. In terms of religion, Hindus were 37.6 percent, Muslims 51.9 percent, Sikhs 7.3 percent, Christians 1.9 percent, and so-called Others 1.3 percent of the urban population. Yet in rural areas, Hindus dropped to 29.1 percent, Muslims remained at 52.5 percent, and Sikhs rose to 15.3 percent. See Khan $(1933,11,89,96,98)$.
} 
(c. 1270-1350), and especially Ravidas (c. 1450-1527). Officially this category returned over four hundred thousand adherents, nearly a third of all lower castes by some estimates, and may have included tens of thousands more who were misidentified, ignored, or coerced into declaring themselves differently. ${ }^{4}$ Thus not only were alternative religious traditions without formal caste hierarchy already available in Panjabi society, but lower castes had effectively preempted the call to leave the Hindu faith by establishing their own distinct religion (Jodhka 2000; Puri 2003; Ram 2004). While Ambedkar recognized the scriptural critique of caste in Sikhism, and even invoked Guru Nanak (14691539) with the Buddha as ardent opponents of the sanctity of the Shastras (Ambedkar [1936] 1979, 54, 69), he acknowledged neither the Ad Dharm movement nor the circumstances of the largely landless agricultural laborers constituting Panjabi untouchables. If caste was a perverse division of laborers as much as of labor, then the program for its annihilation appears to miss the specific logic of its operation in rural Panjab (see Breman 1974; Gidwani 2008; Prakash 1990; Prashad 2000; Rawat 2011).

In this article, I explore the politics of conversion through the problem of lower castes freeing themselves from Brahminical Hinduism but not the constraints of lowliness or casteism in early twentieth-century Panjab (see Bayly 1999; Dirks 2001; Pandian 2007; Rao 2009; Viswanath 2014). I begin with mapping the changing constellation of names across different religions for groups of lower castes, designated as village menials by the colonial state. Next I trace shifts in religious affiliation of these groups amid the emergence of the Ad Dharm movement and its attempt to impart equality, dignity, and community to Panjabi Dalits. To bring this new sense of caste identity to bear on actual labor practices, I then examine the fraught relationship between landed cultivators and landless laborers working side-by-side yet remaining profoundly separate and unequal. That a large proportion of lower castes could adopt religions other than Hinduism or start their own and yet remain excluded and exploited reveals the limits of a politics centered on conversion. It is the antinomy between emancipatory discourses and exploitative relations that suggests the need for a different horizon for overcoming caste hierarchy.

\section{Naming Labor in Rural Panjab}

Who were these "menials" who might have attended Ambedkar's speech in Lahore? According to a conventional colonial description, "the village servants or menials are paid by the zamindars usually in grain at the time of harvest, in return for work performed during the preceding half-year." Formally they were divided into two groups ostensibly based on caste occupations. First were those directly connected with agricultural operations: namely the Tarkhan (carpenter) making and repairing wooden plows and other

\footnotetext{
${ }^{4}$ The colonial state usually referred to lower castes in this period as "depressed classes." Out of a population estimated at 1,422,009 in 1931, the official figure for followers of Ad Dharm is 418,789, including 113,580 from Jalandhar, 111,829 from Hoshiarpur, 50,718 from Lyallpur, and 36,262 from Ferozepur. Khan Ahmad Hasan Khan, the author of the census report, briefly mentions that a "tug-of-war" started in some districts between Ad Dharmi activists and Hindu and Sikh landowners over the religion lower castes were declaring to census enumerators. See Khan (1933, iii-iv, 294, 318, 374).
} 
implements as well as the apparatus for well irrigation; the Kumhar (potter) providing various earthen vessels for wells and domestic use; the Lohar (blacksmith) forging and sharpening plowshares along with other iron tools; the Chamar (leatherworker) making leather bags, whips, and blinkers for bullocks; and the Churha (sweeper) providing brooms, baskets, and ropes. Second were a greater variety of those more distant from agriculture but still a part of village life, mainly the Nai (barber), the Dhobi (washerman), the Darzi or Chhimba (tailor), the Julaha (weaver), the Jhinwar or Mehra (water-carrier), and the Mirasi (musician), among others (Saunders 1873, 61-62). Although sharing some features with supposedly caste-based occupational roles elsewhere in north India, the authority of Brahmins was conspicuously absent in colonial rural Panjab (Tandon 1968, 76-77; cf. Brard 2007). ${ }^{5}$

In the first group of village menials, the first three castes were fewer in number and occupied a somewhat higher status, as they worked in their own small shops at their own pace, and increasingly took on piecework for cash remuneration. Similarly, members of the second group were also numerically few, and mostly confined to their given tasks due to the specialization of equipment and skills. The Chamars and Churhas, on the other hand, were considered the lowest and most stigmatized of castes - untouchables - and constituted the bulk of the menial population. Yet while the colonial vocabulary relied on these simplistic categories, groups identified as "Chamars" or "Churhas" did not use those designations for themselves, nor were they exclusively recognized by them in the wider society. The Panjabi words they adopted reveal a remarkable spectrum of emerging and intertwining caste and religious identities.

Significant lower-caste conversion to Sikhism began in the seventeenth century, to Islam hundreds of years earlier, and to Christianity in the late nineteenth century. Chamar, deriving from chamri for skin or more precisely animal hides, served as a generic term for leatherworker, nominally Hindu. In the northern hill areas they were sometimes termed Dagis or Kolis. Those who converted to Islam called themselves Mochis, closely affiliated with shoe-making, while those who became Sikh took the name Ravidasia after Bhagat Ravidas, which could also be given as Ramdasia or Raidasia. For a short while in the mid-twentieth century, all three, as well as some Julahas who called themselves Kabir-panthis after their acclaimed ancestor Kabir, identified as Ad Dharmi or the followers of the Ad Dharm movement.

Churha, on the other hand, is without an assumed etymological basis, but is presented in colonial writings as another major untouchable caste of Hindu sweepers and scavengers. Converts to Islam became known as Mussalis or Kutanas, Sikhs identified as Mazbis or Rangretas, and Christians were termed Masihs. Those remaining Hindu also changed their designation, preferring to be called Valmikis (or Balmikis colloquially) after Rishi Valmiki, the author of the epic Ramayana (see Judge 2003, 2990). The two

\footnotetext{
${ }^{5} \mathrm{~A}$ well-known description of the lack of Brahmin power in rural Panjab at the turn of the century is from the autobiography of Prakash Tandon, a Khatri who received his education in England and went on to become a top manager in a large multinational company. "That they [Brahmins] could be the leaders of society, in a position of privilege," he writes, "I only discovered when I went to live outside the Punjab. With us the Brahmins were an unprivileged class and exercised little influence on the community." And later: "The very address 'oh Pandita' or 'oh Brahmina' had a gentle sarcasm about it." See Tandon (1968, 76-77), and cf. Brard (2007).
} 
generic caste names for these laborers thus conceal a diversity of identities in a continuous process of formation and reformation. And although today it is offensive and illegal in India to refer to anyone as either a Chamar or a Churha, the word "Chamar" is still used for certain caste-oriented associations and has even been invoked positively in popular music by emerging Dalit artists in east Panjab. ${ }^{6}$

The term "menial" is therefore a general and specific diminution, minimizing the various labors performed by these castes as well as underscoring their exclusion from a requisite and valued role within the agrarian economy. "Menial" conjures up the notion of marginal, as a periphery to the already-centered Jatt, a form of labor adjacent to the main, supposedly given work of being a peasant. At the same time, "menial" implies inchoate and provisional, an assortment of explicitly ancillary tasks without fixity or importance to the productive process. Defined as subordinate both to the landholding cultivator and to cultivation itself, the menial laborer thus occupies a position of double subordination. The stigma of an alienated inconsequence permeates the very language by which these groups were located within the political economy of the countryside.

\section{Conversion, Competition, and Community}

During the late nineteenth and early twentieth centuries, lower castes changed religious affiliations and consolidated community boundaries to gain a new kind of social and economic preponderance. Here the colonial census was crucial in creating awareness of the relative strength of a group and the possibility of tracking its trajectory over time (Appadurai 1993; Cohn 1987; Jones 1981). In the first comprehensive all-India census of 1881, undifferentiated Chamars numbered 1.4 million and Churhas 1.1 million in Panjab. This was less than Jatts (4.4 million) and Rajputs (1.7 million), roughly equal to Brahmins (1.1 million), but more than other prominent groups such as Pathans $(859,000)$, Gujars $(627,000)$, and Khatris $(419,000) .^{7}$ In a process officials admitted was replete with inaccuracies, approximately 68 percent of Chamars were returned as Hindu, 25 percent as Muslim, and 7 percent as Sikh, while 58 percent of Churhas were Hindu, 37 percent Muslim, 4 percent Sikh, and 1 percent Christian. Together Chamars and Churhas constituted the second-largest caste group in Panjab, and were recorded as mostly following strands of what at the time was a diverse, amorphous Hinduism.

Over the next forty years, the proselytizing efforts of Christian missionaries transformed the act of conversion into a concerted competition among the Arya Samaj, the

\footnotetext{
${ }^{6}$ The Chamar Mahan Sabha, or "Grand Chamar Society," is a prominent Jalandhar-based organization that advocates on behalf of scheduled castes in Panjab, particularly Ravidasias. In recent years, a number of songs with titles such as "Putt Chamaran De" (Sons of Chamars) and lyrics boasting of the physical strength, material possessions, and self-respect of Chamars have become popular in certain lower-caste communities. The titles and content of these songs can be seen as mimetic responses to perhaps one of the most famous Panjabi songs, "Putt Jattan De" (Sons of Jatts) sung by Surinder Shinda in 1981.

${ }^{7}$ The 1881 census shows Chamars numbered 1,072,699 in addition to 349,272 Mochis, while Churhas were 1,078,739. The figures for other castes are: Jatts 4,432,750, Rajputs 1,677,569, Brahmins 1,084,193, Pathans 859,582, Gujars 627,304, and Khatris 419,139, out of a total population of $22,712,120$. See Ibbetson (1883, table VIII A, "Statement Showing the Distribution of the People by Tribe, Caste, and Religion," 4-10).
} 
Singh Sabha, Sunni Anjumans, and the Ahmadiyya movement (Harding 2008; Jones 1976; Oberoi 1994). As a result of this protracted, multifaceted struggle, as well as different practices in counting, the distribution of lower castes across the major religions changed significantly by the 1921 census. Chamars (including Mochis and Dagis) now stood at 1.7 million, with those professing to be Hindus decreasing to 66 percent, Muslims remaining at 25 percent, and Sikhs increasing to 9 percent. Churhas (with Mussalis, Mazbis, and Christians) totaled 1.4 million, but with Hindus dropping to 48 percent, Muslims down to 26 percent, Sikhs rising to 7 percent, and Christians jumping to 19 percent. ${ }^{8}$ Thus in four decades almost 2 percent of Hindu Chamars (68 to 66 percent) and 10 percent of Hindu Churhas (58 to 48 percent) appeared to officially leave Hinduism, mainly for Sikhism and Christianity.

A more dramatic assertion of lower-caste religious identity took place over the following decade. Rather than leaving one faith for another, however, this change entailed the creation and adoption of a new one altogether. In early June 1926, a small group of Chamars met in the village of Mugowal in Hoshiarpur district to discuss ways of concentrating lower-caste power amid upper-caste cooptation and competition. The village was the birthplace of Mangoo Ram, at the time a schoolteacher who would become the leader of the movement and an influential if somewhat overlooked figure in Panjab politics before and after independence. In a series of interviews with the anthropologist Mark Juergensmeyer in the 1970s, he related the extraordinary details of his life before his death in 1980 at the age of ninety-four.

Born into a family of leatherworkers, Mangoo Ram's father had become a successful wholesale supplier of leather-goods to the British Indian Army, and insisted that his son be educated to help with the business. Despite excelling at school, Mangoo Ram was often the only untouchable student in the class, forced to sit at the back of the room or even outside, listening through an open door. In 1909, he convinced his father to send him to America in order to work and support the family through remittances. While Ambedkar was studying for a master's degree at Columbia University in New York, Mangoo Ram picked fruit in the orchards of the San Joaquin Valley in California before joining the militant anti-colonial Ghadar Party in 1913 (see Puri 1993; Ramnath 2011). Compared to the discrimination he faced growing up, he later fondly recalled the equality and camaraderie of the Ghadar militants, even though he was only one of two Chamars in a group of mostly Jatts. Two years later, he volunteered to smuggle weapons to Panjab to incite an uprising against British rule, but was discovered en route and almost executed, spending several years in jail and then in hiding in Manila. Mangoo Ram eventually made his way back to Panjab by 1925, where he founded a school and taught briefly before turning his attention to the condition of untouchables (Juergensmeyer 1982, 283-89).

The 1926 meeting in Mugowal produced a group dedicated to articulating and organizing around a distinct narrative of lower-caste history, religion, and identity. Rather than

${ }^{8}$ In the 1921 census there were 1,139,741 Chamars, 434,682 Mochis, and 165,164 Dagis, while there were 749,687 Churhas, 366,098 Mussalis, 281,946 Christians (without a specified caste), and 65,004 Mazbis. The religious proportions are given within each caste category. See Middleton and Jacob (1922, table XIII, "Caste or Tribe," 194-254; table XV, "Territorial Distribution of the Christian Population by Sect and Race," 264-72). 
strict religious piety, these individuals were motivated by a restless ambition, "socially sensitive and politically astute" (44). For Mangoo Ram the history of Panjab was a long sequence of destruction and displacement for untouchables. As the original inhabitants of the land, they were first suppressed and enslaved by Aryan invaders, with each generation of Hindus worse than the one before and Manu- a mythical figure presumed to have written the ancient Brahminical law code-in particular denounced as a "murderer." Islam at first held some liberating potential but quickly absorbed and reproduced the same logic of caste hierarchy, while Sikhism was little more than a momentary upsurge ending in tyranny. Against this past, Mangoo Ram and his followers argued that all untouchables_-"chamars, chuhras, sansis, bhanjre [and] bhils" (45)—-together constituted a separate qaum, usually translated as nation but here referring to religious community, equal to Hindus, Muslims, and Sikhs. To reclaim their autochthonous status, the group took the name Ad Dharm, meaning the originary or ancient faith, and identified a quartet of figures as their founders: Valmiki, Namdev, Kabir, and especially Ravidas. By recognizing themselves as Ad Dharmis, the group believed untouchables would at last achieve parity with other religious communities rather than continue to be manipulated and subsumed within them.

Predictably the new assertion provoked serious conflict with existing organizations competing for untouchable allegiance. The Arya Samaj was seen as the greatest enemy. Many Ad Dharm leaders emerged from it or one of its affiliates (such as the Jat-Pat Todak Mandal), and were constantly enticed to return to work for untouchable uplift within its larger neo-Hindu framework. Faced with the threat of reabsorption, Mangoo Ram focused on condemning the shuddhi or "purification" campaign as a devious attempt to keep untouchables imprisoned within the grasp of Hinduism (see Adcock 2013). In a group whose name literally meant the "Society of Aryans," he argued, there could be no space for equality with non-Aryans.

On the other hand, the Ad Dharm both faced and exhibited hostility of a different kind toward the Singh Sabha movement. Here the tension was more intricate: the Sikh Gurus had denounced caste and declared the equality of all; the Adi Granth included verses from lower-caste Bhagats venerated by all Sikhs; and Sikh institutions deliberately transgressed the boundaries of purity, pollution, and distance. Yet as Mangoo Ram argued, it was also true that untouchables - whether professing to be Hindu, Muslim, or Christian, or even Mazbi or Ravidasia Sikh-remained largely untouchable for both Khatri and Jatt Sikhs, and that cruel and degrading treatment continued almost unabated in Sikh-dominated villages. Lower castes still lived in separate areas, could not access the same wells, and were exploited for their labor; they were also discriminated against within many gurduaras through outright exclusion, different seating arrangements, and restrictions on participation in the collective kitchen known as langar (Hans 2016, 142-47; Jodhka 2002, 1814-20; Puri 2003, 2697; Ram 2007, 4068-70). At the same time, some Singh Sabha activists, such as Giani Ditt Singh and Kahan Singh Nabha, recognized this contradiction and had been directing energies toward exhorting Sikhs to live up to the values of their own faith (see Puri 2003, 2697). Nevertheless, Mangoo Ram and the Ad Dharm would not be mollified by such attempts, however sincere. To mark their separation from Sikhism, they transformed the status of Ravidas, Kabir, and Namdev. No longer were they simply respected Bhagats, but Gurus in their own right, and thus the progenitors of an entirely new faith. 
Ad Dharm's efforts bore unexpected and unprecedented results in the 1931 census. A few years before, Mangoo Ram sent a petition to the governor of Punjab demanding a separate designation: "We are not Hindus. We strongly request the government not to list us as such. Our faith is not Hindu but Ad Dharm. We are not a part of Hinduism, and Hinduism is not a part of us." The administration readily obliged, as the group's hostility toward the Arya Samaj as well as Gandhi and the Congress made it seem at best indifferent to colonial rule. Indeed, concurring with Ambedkar on the critique of independence for a caste-ridden society, another part of the Ad Dharm program stated: "India should not be given independence until Untouchables are free and equal. Otherwise it would be a disgrace to the British rule" (Juergensmeyer 1982, 301). The census results came as a shock to everyone involved. Despite a campaign of intimidation "not infrequently bordering on terrorism" (Khan 1933, iv), approximately 418,789 people identified themselves as Ad Dharmis, mainly in the districts of Jalandhar, Hoshiarpur, and Lyallpur. Leaders later claimed that the actual number of people wanting to identify with Ad Dharm was close to two million (Juergensmeyer 1982, 77).

Equally significant was the changing distribution of lower castes in the other religions. The population of Chamars (this time including Dagis, Mochis, and Ramdasias) increased to slightly less than 1.9 million, of which Hindus were reduced to 47 percent, Muslims again remained at 25 percent, Sikhs rose to 12 percent, and Ad Dharmis became 16 percent. Out of 1.5 million Churhas (with Mussalis, Mazbis, and Christians), Hindus dropped even lower to 24 percent, Muslims rose a little to 29 percent, and Sikhs to 11 percent, while Christians surged to 30 percent and $\mathrm{Ad}$ Dharmis now made up 6 percent. Thus within a decade, almost one-third of Hindu Chamars and one-half of Hindu Churhas changed their religion (Khan 1933, 282302). Between 1881 and 1931, the absolute number of Hindu Chamars actually decreased from 963,000 to 885,000 while Hindu Churhas went down even further from 629,000 to 367,000. As Mangoo Ram noted with satisfaction, in less than five years the Ad Dharm converted roughly the same number as Christian missionaries did in fifty years (Juergensmeyer 1982, 77). Thus well before Ambedkar was to give his speech vowing to leave Hinduism, lower-caste Hindus in Panjab had by and large already severed their ties, adopting Sikhism, Christianity, or their own Ad Dharm faith.

By combining existing devotional figures with new doctrines and practices within a stirring narrative, the Ad Dharm created a distinct identity for Panjabi untouchables. Its success lay in harnessing the popular respect for Ravidas, Kabir, and Namdev into a reverence bordering on deification. Mangoo Ram's comparison with Christianity is therefore more than mere boasting. Whereas missionaries had to impart a totally unfamiliar history and theology to lower castes, the Ad Dharm invoked figures already a part of the local imagination and linked to a long tradition of inquiry, critique, and assertion. An iconoclastic weaver from Benares speaking in a familiar idiom resonated more intensely than a carpenter turned messiah from Nazareth.

Yet the centrality given to figures from these specific occupational backgrounds also limited the appeal of Ad Dharm and contributed to its eventual decline. Since most of its leadership were Chamars from Jalandhar and Hoshiarpur who exalted Ravidas in particular, the vast majority of adherents were also Chamars, Ravidasias, Dagis, and even Mochis. Despite its efforts, the Ad Dharm did not manage to overcome divides internal to lower castes to attract significant numbers of Churhas, Mussalis, Mazbis, or Masihs. 
When Mangoo Ram reached out to Ambedkar, supporting him against Gandhi's blackmail over separate electorates in Pune and offering to merge Ad Dharm with his organization, the reply was somewhat distant. According to Juergensmeyer, Ambedkar "wanted to join, not a separatist religious tradition, but rather an egalitarian one, which would embrace the whole of society"-hence his temporary interest in Sikhism and ultimate conversion to Buddhism shortly before his death in 1956 (Juergensmeyer 1982, 162; cf. Kumar 2015, chap. 5; Skaria 2015; Viswanathan 1988, chap. 7). ${ }^{9}$ Thus the very elements that had informed and advanced the Ad Dharm movement ended up isolating it.

After the watershed of the 1931 census, and another surprising showing in the 1936 legislative elections, Ad Dharm leaders became embroiled in factional controversies and political maneuvering, and drifted from the task of developing their qaum. Although their momentum faltered and the movement declined, Juergensmeyer points out that its leaders "established a fact which previously had been unproved." They demonstrated "that Untouchable castes were capable of mobilizing for their own benefits, and of organizing in ways that permitted them to compete under the conditions that governed the sociopolitical arena at large" (Juergensmeyer 1982, 80, 152-55; cf. Gilmartin 1988, chaps. 4-6; Ram 2008). In little over a decade, Ad Dharm transmuted untouchability from layers of negation into the basis for a new, politically informed religious community in Panjab.

\section{Dividing LABOR AND Laborers}

The Ad Dharm assertion of a proud, originary community did not rest entirely on refuting identification with the untouchability of Hinduism. Equally important, though receiving far less scholarly attention, was its challenge to the supposedly traditional alignment between caste and occupation. The simple, stifling equation of Chamar as leatherworker or Churha as sweeper was deeply implicated — and just as debilitating — as being labeled an outcaste Hindu (see Prashad 2000; Rawat 2011, chaps. 2-3). Two stark points

\footnotetext{
${ }^{9}$ The nature of the problem of caste and Sikhism is perhaps best illustrated by a lesser-known aspect of Ambedkar's attempt to find an alternative religion for untouchables. According to Harish Puri, after declaring he would not die a Hindu in 1935, Ambedkar began research into different religions and even came close to choosing Sikhism in June 1936. Soon after, however, the plan was suspended, and then quietly dropped. While doubts remain over his ability to reach consensus with certain constituencies among his own followers, a more persuasive explanation for the change relates to conflict within the Sikh community. On the one hand, some lower-caste Panjabis (perhaps Hindu or even Mazbi or Ravidasia Sikh) conveyed to Ambedkar "the atrocities they suffered at the hands of the dominant community of jat Sikhs and appealed to him to ensure that the untouchables never became Sikhs." On the other hand, some upper-caste Sikhs became alarmed at what this influx would mean for them. While the potential addition of approximately sixty million untouchables to the existing four million Sikhs would raise their number fifteen-fold across India, it would also irrevocably transform the caste composition of the community. In a vulgar comment capturing the mindset of the elites, one leader is said to have explained the matter rhetorically: "By making six crore untouchables Sikhs, should we hand over the Darbar Sahib [the premier Sikh gurduara in Amritsar] to Chuhras?" Upper-caste Sikhs had little interest in an exponential expansion of their religion if it required a redistribution of power with lower-caste Sikhs. See Puri (2003, 2698); Hans (2016, 143-48).
} 
coming out of the program from the 1926 meeting at Mugowal make explicit this rejection:

12. We are agriculturalists; we know our work well. But we are not paid enough in agricultural wages. We cannot take care of our families properly. Vacant lands should be given to the Untouchable community.

13. The government should treat agriculturalists from the Untouchable class on par with agriculturalists from other communities, especially in Lyallpur, Sheikupura, Sargoda, Montgomery, and Multan. In these districts, there should be more land for Untouchables and more employment. (Juergensmeyer 1982, 300-301)

This affirmation of agriculturalist status-emanating from the premium placed on that category in the Punjab Alienation of Land Act of 1901 (Barrier 1966; Islam 1995; Nazir 2000)_raises the question of untouchable economic as opposed to religious identity.

Rather fortuitously, around this same time the Panjab administration happened to be conducting a series of investigations into the internal dynamics of the agrarian economy. The Board of Economic Inquiry, a government-funded research body established at the turn of the century, sent local interviewers to over a dozen villages for twelve months to record details of both the expenses and returns of cultivation and the patterns of consumption and reproduction by families of landholding proprietors. Just as Ambedkar was demanding separate electorates, and Mangoo Ram was enjoying the census windfall, rural labor practices were coming under new scrutiny from the colonial state.

The most startling revelation from these studies of "peasant" cultivation is an admission of the very impossibility of that object of inquiry. R. K. Seth and Faiz Ilahi's survey of the village of Durrana Lanhana in Multan district states the problem directly:

It will thus appear that it is not possible to describe the working life of an isolated cultivator as such with any accuracy. It is invariably so much intermingled with that of his colleagues and members of his family that one might as well consider the combination as a unit for the purposes of the present inquiry. (Seth and Ilahi 1938, 30-31, emphasis added)

Agrarian production could not be reduced and singularized into the discrete labors of a lone peasant. The collective nature of the enterprise meant recognizing and tracking the contributions of different groups within the village. Instead of the north Indian jajmani system (Commander 1983; Mayer 1993), however, the researchers termed what they observed as the sepidari system, a similar arrangement of castes performing various labors in exchange for shares in grain: Kumhars providing pots, Mehras carrying water, a Pandit or Mullah offering solace.

For instance, the study from Kala Gaddi Thamman in Lyallpur notes that for making and repairing one plow for a cultivating landowner, a Tarkhan received fifty pounds each of wheat and maize, one bundle of unthreshed wheat, and four bundles of green fodder a year. In addition, he would receive one rupee plus a measure of cloth at the birth of the cultivator's first son, two rupees on the marriage of a son, three rupees on the marriage of a daughter, and a quarter of a rupee on the death of a family elder in exchange for several 
smaller duties (R. Singh 1932, Appendix A 17-18). Yet in Panjab this system differed for being largely a product of makeshift custom, wedded neither to age-old beliefs nor a religious order, and far less rigid than conventional representation of jajmani as a fixed law (Bhattacharya 1992, 154-65; Kessinger 1974, 56-75). The performance of tasks seemed to matter more than the identity of the person performing them. Also, the researchers noted that sepidari itself was declining as a form of organizing village relations. From the late nineteenth century onward, the growth of the canal colonies and military recruitment offered greater opportunities for lower-caste mobility, while the rise of commodity production, market prices, and piecework monetized (and standardized) the process of remuneration (see Mazumder 2003).

Beyond the village-wide constellation of castes and roles, a specific relationship captured the attention of the Board researchers. They reported a common form of labor attachment throughout Panjab called siri, where landholding cultivators would contract with landless laborers to provide various agricultural services for an entire season in exchange for a proportion of the harvest. This was not a form of tenancy with an absentee landowner, nor was there a fixed list of tasks to perform or items to deliver as in sepidari arrangements. Although sometimes termed "field laborers," siris resembled constant yet unequal companions in agricultural operations, working alongside "cultivators-proper" in every aspect of cultivation (Jodhka 2002, 1816; Ram 2004, 899; cf. Prakash 1990; Viswanath 2014).

Almost all landholding households in Panjab had some form of siri relations. Their payments were based on a share of the produce and food from the cultivator's home, as well as cash advances and other types of patronage. Perhaps most importantly, the kinds of labor they performed were far removed from their caste identity. Whereas a Lohar would be translated into "blacksmith" by virtue of possessing requisite equipment, training, and capital, and therefore be expected to provide plowshares and sickles, the vast majority of siris were Chamars and Churhas performing tasks unrelated to leather or sweeping. In the tedious gamut of colonial caste classifications, there is no "traditional" designation for multifarious agricultural laborers because the supposed fixity of untouchable caste-work unraveled precipitously in the countryside.

The study of Gaggar Bhana in Amritsar, for example, describes how Churhas in particular diverged from their stigmatized label as sweepers, which included removing human feces (euphemistically called "night soil") from the homes of landlords. The "rural Chuhra," explains Sardar Gian Singh, "has nothing to do with the removal of night soil, which is the principle occupation of the town chuhra." The reason for this discrepancy is the unique spatial configuration of the fecal economy: there is "practically no night soil to be removed because there is no system of latrines in the villages." Instead, "when necessity arises the fields near the village are used" (S. Singh 1928, 25). In other words, the supposedly traditional occupation of the Churha only manifested in the confines of the modern city. In the villages of Panjab, the vast majority of Chamars, Churhas, and other lower castes performed the labors of cultivation under the sign of a siri.

What was the nature of the relationship between cultivator and siri? ${ }^{10}$ Fortunately, the survey of Suner in Ferozepur contains a rare translated copy of an agreement signed

${ }^{10}$ Perhaps the most vivid depiction of contemporary siri laborers is from the song "Jatt te Siri da Haal" (The Condition of a Jatt and Siri) by the radical leftist poet Sant Ram Udasi from the late 1970s. For more, see Rahi (2011, 174). 
by two individuals on June 29, 1932. Titled "Specimen of agreement between cultivating owner and his siri," it begins with the following sentence: "I, Chaugutta, son of Karmunby caste weaver - am a resident of Village Suner, Tahsil Zira," and am taking a sum of sixty rupees from Tehl Singh, son of Hazara Singh, "to meet my household expenses." The loan will be repaid after a full year starting from the first of Har (mid-June, after the wheat harvest) but without interest because during that period "I will be working as siri with Tehl Singh." Chaugutta agrees to "look after his cattle and serve him generally as I am ordered," which may entail sleeping beside the cattle at night, in return for onefifth of the grain produced from the area cultivated by one plow. In addition he will receive meals from the household of Tehl Singh, but will not have access to green fodder from his land. The agreement then stipulates that if Chaugutta misses more than three days of work in the year, he will be responsible for paying the day-wages of any laborer Tehl Singh hires as a temporary replacement. If for any reason he breaks the agreement altogether, both his share in grain will be forfeited and he will have to immediately repay his original loan plus 50 percent interest. At the bottom are the date and name of a witness (one Atma Ram) alongside Chaugutta's age (twenty-five) and space for his thumbprint (Dawar 1936, Appendix B 24).

Such a short, simple document is in fact brimming with disparities of power. Chaugutta's use of the first-person pronoun indicates he is the speaker, but the voice of Tehl Singh resounds throughout. All of the declarations are the duties of the former to be carried out during fixed periods for certain payments against specific consequences. Tehl Singh makes few commitments beyond the initial loan. His caste and age are not disclosed, nor is there even a place for his signature, reflecting how this document was for his use, kept in his possession to add the authority of a written contract to his considerable existing leverage in case Chaugutta became incompliant. There is also a revealing unevenness in the details of the agreement. While it clearly states the amount of money borrowed; dates for repayment and work; entitlements for food, fodder, and the harvest; and the types of penalties, it is silent on what exactly Chaugutta is supposed to do. Aside from caring for Tehl Singh's cattle, he commits to serving "generally" as "ordered." The logic of the ambiguity of laboring tasks becomes clear against the backdrop of the calendar of agricultural operations.

Most of the village studies provide month-by-month descriptions of the labors of cultivation during a given year. In Suner, for example, starting in the middle of June most of the fields were plowed and spread with manure while cotton was planted and the sugarcane fields irrigated from the canal; the sowing for maize began in July with regular watering from wells; after the rains in September other crops such as oilseed and chickpeas were sown; in November sowing of wheat and some barley began; by late December the cotton crop was picked, and oilseed harvested; in January the wheat required a few well waterings; from February onward the sugarcane was pressed and its juice boiled; in March the area for sugarcane was replowed and replanted and the chickpeas harvested; canal water resumed in April for sowing cotton, which also marked the beginning of the wheat harvest; May and early June were dedicated to threshing wheat, transporting grain to market, and gathering straw; and at that point, the new year commenced with yet more plowing. Tasks for livestock fodder such as regular plowing, irrigating, harvesting, and replanting; daily feeding and washing of animals; repairing fences on cotton and sugarcane fields; and clearing irrigation channels from canals also continued 
throughout the year. According to colonial calculations, while the average hours worked in a day ranged from just two in July to over fifteen in May, the number of workers needed per month was never fewer than three and sometimes up to nineteen (S. Singh 1928, 33-36). These are the myriad labors that Chaugutta would do alongside Tehl Singh, his relatives, and perhaps others. Put differently, there was no single task that only one or the other would perform, and therefore no single cultivator-hence the Ad Dharm assertion that untouchables were in fact agriculturalists.

The intertwined, indistinct quality of caste labors is evident in the everyday experiences of cultivation. According to the surveys, during the summer season (April-September) a typical day for a landholder and a siri would begin at sunrise with an empty-stomach departure for the fields. After working until 7:00 or 8:00 a.m., they would eat a small meal consisting of lassi (buttermilk) and one or two rotis (unleavened bread) with gheo (clarified butter) brought to them from the cultivator's home, presumably cooked by his wife and/or other household women. Work resumed until around midday, when a more substantial meal of several rotis with gheo, pickled or cooked vegetables along with some gur (unrefined sugar) and more lassi would again be delivered, followed by more work until the approach of sunset. At that point the cultivator and siri would return to eat the last meal in the former's home, or sometimes separately, consisting of the same rotis and gheo, but now with lentils or, very rarely, some goat or chicken. ${ }^{11}$ In Chaugutta and Tehl Singh's situation, a Julaha and presumably a Jatt would thus eat the same food, from the same source (though probably with different utensils, if used), for at least two out of their three daily meals.

Set against the leveling aspect of food consumption, the inequities of this relationship manifested most sharply at harvest. Here the difference of ownership conferred upon the cultivator the power to pay the siri a portion of the grain they and others produced together. The survey of Gijhi in Rohtak provides a detailed account of the expenses and returns for several cultivators. "Farmer A," for example, cultivates twenty-eight acres of land with a siri (called a "servant"). Throughout the winter and spring seasons, he spends approximately Rs. 290 on the upkeep of three bullocks, Rs. 48 on maintaining a cart, and Rs. 23 on various implements (given to sepis such as the Tarkhan and Kumhar), as well as paying Rs. 117 in land revenue. The siri receives the value of around Rs. 8 in cash and slightly less than Rs. 6 in food per month ( 3 anna a day), for a total of Rs. 164. At harvest, the primary winter crops of wheat and chickpeas plus different fodders, millets, sugarcane, and cotton from the summer generates |Rs. 1,540. After deducting expenses from the yield, Farmer A therefore nets around Rs. 898, or more than five times as much as the siri. ${ }^{12}$ The logic of colonial revenue and the rule for calculating net assets both permitted this disparity and erased it from view. By

\footnotetext{
${ }^{11}$ With shorter days in the winter season (October-March), the number of meals would be reduced to two (at 11:00 a.m. and 6:00 p.m.) but with more gheo and sometimes barley or maize replacing wheat, while during the spring harvest a fourth meal of rotis and gur would be eaten around 4:00 p.m. Only ex-soldiers had developed the habit of drinking tea by this time, while opium was consumed far more regularly than alcohol. Cultivators also enjoyed greater access to gheo and milk because they owned more and better-producing buffalos. See Dawar (1936, 170-71); Seth and Ilahi (1938, 266-70); R. Singh (1932, 153-57); S. Singh (1928, 182-83).

${ }^{12}$ There is a discrepancy in the specific numbers used for Farmer A's income and expenses over five pages of calculations and the summary chart on the last page of this section. The occupier rate of Rs.
} 
classifying the siri as an expense for the cultivator, akin to maintaining a plow or digging a well, the political economy of this relationship is effaced by the routine keeping of accounts. A human being becomes just another reified item on the balance sheet of an agrarian enterprise.

Yet the siri was never merely an input within a process but an individual with material and social needs, desires, and agency within a changing society. The imputed formalism of the relationship is belied by brief disclosures of discontent and maneuvering at each end of the hierarchy from the village surveys. Elements of wellbeing, fairness, and trust became the terrain of constant if unspectacular contestation. In Gaggar Bhana, the researcher notes that although siris "are always allowed to eat as much as they want" from the cultivator's home, "it is a common cause of grumbling among the small farmers that their laborers eat away their profits" (S. Singh 1928, 185). The situation could be more acute, as in Gijhi, where some landowners would force field laborers to work for rates lower than what they could receive outside the village. "In these circumstances it is not surprising that the relations between the zemindars and the kamins are very strained," requiring village panchayets (councils) to mediate. The struggle, however, was between uneven parties: despite the boldness of the kamins, the report points out, "the threats of the zemindars to refuse permission to the kamins to graze their cattle in the village waste, which is the property of the owners, and fear of starvation, soon reduced them to submission" (Narain 1932, 16, emphasis added).

More obliquely, the apparent solidity of custom would bend under a shifting balance of power. At harvest, laborers were entitled to an extra bundle of unthreshed wheat at the end of each day. Usually they would take a small bundle, worth a quarter of a rupee (4 anna), but if they "know that their employer cannot do without them they bring away as heavy a bundle as they can carry worth about 8 annas" (17). Beyond such sleights, subversion could also be more organized, and therefore more substantial. In Suner, the researcher reports that two siris guarding the crop "of their master" entered into "a conspiracy and managed every day to take away some grain which they kept collecting at one place." Soon they were caught, leading to a panchayet meeting where it was decided to settle the issue internally by making them return the stolen grain-amounting to over a thousand pounds - and pay a fine of ten rupees. After the resolution, however, two policemen "happened to reach the village and hearing of the matter called the two culprits and, it was alleged, took [a further] Rs. 5 each from them" (Dawar 1936, 88). In these and countless other ways, the apparent order and reciprocity between cultivators and siris was in fact riven with constant if not open turmoil. Tehl Singh's contract is so askew because Chaugutta could resort to straining customary entitlements, pilfering grain, evading tasks, and even escaping the village to preserve or improve his own meager position (see Guha 1983; Scott 1985).

Cultivation in early twentieth-century Panjab thus permitted neither a discrete division of labor nor laborers. Indeed, siri participation interrupts the narrative of menial laborers as ancillaries in the shadow of the autonomous peasant. Throughout the colonial period and beyond, a person plowing a field or harvesting a crop would just as likely be a

69 is also not included in the land revenue figure. In the summary, gross income is Rs. 1,602 and expenses are Rs. 1,014 for a profit of Rs. 588. See Narain (1932, 199-203, 213-22). 
Jatt as a Chamar or Churha. Their relationship might better be described as an asymmetrical agreement between two caste-bound individuals—one with land and its entitlements and the other without-combining their labor in order to cultivate the holdings of the former. Yet even this binary is complicated by the fact that the two parties performed parallel tasks and consumed similar foods (though not in identical quantities) while receiving disproportionate shares from the same harvest. As noted by one researcher, in rural Panjab "social taboo on account of the neglect of observance of caste regulations is practically unknown" (Bhalla 1922, 142). The collective labors of cultivation therefore both erased and obfuscated caste hierarchy, by ignoring the most obvious proscriptions on segregated exertion while strictly upholding a stark disparity in returns.

\section{Overcoming the Caste Question?}

The political economy of Dalit conversion challenges the conventional framing of the question of caste in at least colonial Panjab. It reveals a critical limit to Ambedkar's arguments from Annihilation of Caste. By the early twentieth century, the call for untouchables to abandon Hinduism had been preempted not only by longstanding conversion to Sikhism, Islam, and later Christianity, but also by nearly a decade of independent lower-caste organizing. After its founding in 1926, the Ad Dharm articulated a vision of untouchable Panjabis constituting a distinct qaum with its own history, beliefs, and traditions on par with other religious communities. It registered almost half a million adherents in a census five years before the undelivered Lahore speech. Although its political capacity gradually waned, Ad Dharm created educational institutions and a dispersed devotional network that continues to instill reverence for Ravidas and self-respect among Panjabi Dalits to the present (Juergensmeyer 1982, 152-54; Ram 2007). While Ambedkar's efforts brought untouchable issues to the forefront of a new, all-India audience, much of the content of that struggle had longer, more radical and compelling antecedents.

Despite their differences, Ad Dharm and Ambedkar also held a common solution to the predicament of untouchables. Both believed in and attempted to bring about emancipation in part through conversion into either a new or alternative faith (Ad Dharm or Buddhism). Answering the caste question with religious conversion invokes an adjacent debate from nearly a century earlier in Europe. Karl Marx's 1843 essay "On the Jewish Question" analyzes the limitations of liberalism to address the problem of difference-as-discrimination by contrasting political and human emancipation. He begins by discussing how, during the nineteenth century, many thinkers argued that to overcome the religious bigotry faced by Jews in Christian Prussia, a secular state that recognized the equal rights of all its citizens was required. For Marx, however, this meant forcing individuals to live "a double existence"-artificially split between public citizen and private individual — to only partially relate as equals in one domain of life while continuing to experience discrimination in another (Marx [1843] 1978, 34). Aligning the difference of religiosity with the difference of inferiority, he points out that people "do not cease to be religious by virtue of being religious in private." That is why "the state can liberate itself from a constraint [such as religion] without man himself being really liberated" (32; cf. Birla 2009, 24-27; Mufti 2007, chap. 1; Rao 2009, 21-26). 
Since the exclusion of Jews persists even in a nonreligious state, political emancipation from Christianity does not abolish religious bigotry itself, but merely displaces it from a newly constituted public sphere into a private one, where its effects become normalized as features of immutable everyday life. In this sense, the predicament of the Jew serves as a stand-in for any inequality derived from difference, religious or otherwise, that manages to live on despite its repudiation by the state. The very fact that an individual could be at once both Jew and citizen—subordinate and equal—belies the very claim to overcoming religious disparity in this manner.

The same holds true of property. The "political suppression of private property," argues Marx, "not only does not abolish private property; it actually presupposes its existence." In other words, ownership qualifications for participation in public life might end, but vast disparities in ownership itself would continue unabated. Crucially, Marx extends his argument to other forms of hierarchy, stating the "difference between the religious man and the citizen is the same as that between the shopkeeper and the citizens, between the day-laborer and the citizen, between the landed proprietor and the citizen, between the living individual and the citizen" $(33,34)$. Thus while the secular state "certainly represents a great progress" (35) in denying sanction to certain discriminatory practices, it does not attempt to abolish those practices themselves. Inequities not only remain, but are rendered natural. In contrast, Marx offers human emancipation, a horizon where the values of secularism and equality transcend the confines of the public sphere to penetrate all dimensions of social existence. It is through this prospective, aleatory politics, realized "when the real, individual man has absorbed into himself the abstract citizen" (46), that society might achieve an expansive, holistic emancipation worthy of its potential.

Of course, the distinctive history and shifting conditions of colonial Panjab do not permit any direct application of continental prescriptions. Discussions over religious conversion in fact occurred in a context markedly dissimilar to Western Europe, and with even narrower parameters (see Birla 2009, chaps. 4-5; Chatterjee 1993, chap. 2). Lower castes might emancipate themselves in one sense by abandoning a faith that stigmatized them as inferior and impure. They might also enact this rejection openly, as Ambedkar eventually ceased to seek entry into Hindu temples and Ad Dharm created its own distinct places of worship. The postcolonial Indian state further contributed to this process, perhaps best epitomized in making illegal the very use of caste names such as "Churha." But within the sphere of the agrarian economy, lower castes would have little choice other than to continue in the debilitating labors that structured their daily existence. The stigma of caste was felt not only through spiritual denigration or social distancing, or repeating the perverse injunctions of Manu. It was experienced in the routine of performing much of the same labors as a landholder yet receiving only a fraction of the returns.

What Marx illuminates, then, is the contradictory ideology that underpinned material relations in early twentieth-century Panjabi society. To a Hindu, Sikh, or Muslim landowner, a siri identifying as Hindu, Sikh, Muslim, or even Christian or Ad Dharmi remained a menial laborer. A new qaum could not be equal to other religious communities if the extent of its demand for equality was to seek better employment conditions for its adherents from its antagonists. The politics of Ad Dharm, though effective in rupturing the limits of colonial public/private difference, thus simultaneously encountered another set of limitations. While the world of caste may have been turned upside 
down, it remained at its core the same world and not a new one altogether (cf. Althusser [1969] 2005, 73). We still await a politics with the imaginative capacity and material force to overcome rather than overturn the modern configuration of agrarian caste hierarchy.

Perhaps the real force of Ad Dharm is better appreciated elsewhere, in the realm of dignity, self-confidence, and quotidian empowerment. Its struggle thus cannot solely be measured against an ahistorical standard of "universal" or "human" emancipation. Higher agricultural wages and access to vacant common land continue to be major elements in the landless labor movement in both east and west Panjab today (Akhtar 2006; Puri 2004; Sandhu 2016). Ambedkar too was not unaware of the foundations of this inequity: as law minister of independent India, he finally abolished the Punjab Alienation of Land Act. In this sense, the cancellation of his speech might have been ultimately if unintentionally productive. Instead of appearing as a pragmatic appeal directed to an audience that had already taken more radical initiatives, his text circulated elsewhere across colonial India and beyond as a poignant source of inquiry, provocation, and subversion.

\section{Acknowledgments}

For their critical comments and support, I thank Gyan Pandey, Ritu Birla, Parmbir Gill, and the late Kavita Datla. I also benefited from the discussions generated by presenting versions of this article at Emory University, Amherst College, New York University, Yale University, William Paterson University, the University of Connecticut, and the 2017 "Quest for Equity: Reclaiming Social Justice, Revisiting Ambedkar" conference in Bengaluru, India. I appreciate the suggestions of the Journal of Asian Studies' anonymous reviewers and copy editor, and Jeffrey Wasserstrom. The writing of this article was supported by an Assigned Release Time for Research award from William Paterson University.

\section{List of References}

Adcock, C. S. 2013. The Limits of Tolerance: Indian Secularism and the Politics of Religious Freedom. New York: Oxford University Press.

Aкhtar, Aasim Sajjad. 2006. "The State as Landlord in Pakistani Punjab: Peasant Struggles on the Okara Military Farms.” Journal of Peasant Studies 33(3):479-501.

Althusser, Louis. [1969] 2005. “On the Young Marx.” In For Marx, 49-86. Translated by Ben Brewster. London: Verso.

AmbedkaR, B. R. [1936] 1979. "Annihilation of Caste.” In Dr. Babasaheb Ambedkar: Writings and Speeches, ed. Vasant Moon, 23-96. Vol. 1. Bombay: Education Department of the Government of Maharashtra.

- 2014. Annihilation of Caste: The Annotated Critical Edition. Edited by S. Anand. London: Verso.

Appadurai, Arjun. 1993. "Number in the Colonial Imagination." In Orientalism and the Postcolonial Predicament: Perspectives on South Asia, eds. Carol A. Breckenridge and Peter van der Veer, 314-39. Philadelphia: University of Pennsylvania Press. 
Barrier, Norman G. 1966. The Punjab Alienation of Land Bill of 1900. Durham, N.C.: Duke University Press.

Bayly, Susan. 1999. Caste, Society and Politics in India from the Eighteenth Century to the Modern Age. New York: Cambridge University Press.

Bhalla, Ram Lall. 1922. Report on Economic Survey of Bairampur in the Hoshiarpur District. Lahore: Superintendent of Government Printing.

Bhattacharya, Neeladri. 1992. "Agricultural Labour and Production: Central and South-East Punjab, 1870-1940.” In The World of the Rural Labourer in Colonial India, ed. Gyan Prakash, 146-204. New Delhi: Oxford University Press.

Birla, Ritu. 2009. Stages of Capital: Law, Culture, and Market Governance in Late Colonial India. Durham, N.C.: Duke University Press.

Brard, Gurnam S. S. 2007. East of Indus: My Memories of Old Punjab. New Delhi: Hemkunt Publishers.

Breman, Jan. 1974. Patronage and Exploitation: Changing Agrarian Relations in South Gujarat, India. Berkeley: University of California Press.

Chatterjee, Partha. 1993. The Nation and Its Fragments: Colonial and Postcolonial Histories. Princeton, N.J.: Princeton University Press.

Conn, Bernard S. 1987. "The Census, Social Structure and Objectification in South Asia." In An Anthropologist among the Historians and Other Essays, 224-54. New Delhi: Oxford University Press.

Commander, Simon. 1983. "The Jajmani System of North India: An Examination of Its Logic and Status across Two Centuries." Modern Asian Studies 17(2):283-311.

Dawar, Lajpat Rai. 1936. An Economic Survey of Suner, a Village in the Ferozepore District of the Punjab. Punjab Village Surveys No. 9. Lahore: Civil and Military Gazette Press.

Dirks, Nicholas B. 2001. Castes of Mind: Colonialism and the Making of Modern India. Princeton, N.J.: Princeton University Press.

Gidwani, Vinay. 2008. Capital, Interrupted: Agrarian Development and the Politics of Work in India. Minneapolis: University of Minnesota Press.

Gilmartin, David. 1988. Empire and Islam: Punjab and the Making of Pakistan. Berkeley: University of California Press.

Guha, Ranajit. 1983. Elementary Aspects of Peasant Insurgency in Colonial India. New Delhi: Oxford University Press.

Hans, Raj Kumar. 2016. "Making Sense of Dalit Sikh History.” In Dalit Studies, eds. Ramnarayan Rawat and K. Satyanarayana, 131-51. Durham, N.C.: Duke University Press.

Harding, Christopher. 2008. Religious Transformation in South Asia: The Meanings of Conversion in Colonial Punjab. New York: Oxford University Press.

Ibbetson, Denzil Charles Jelf. 1883. Report on the Census of the Panjab, Taken in the 17th of February 1881. Vol. 2. Calcutta: Superintendent of Government Printing.

Islam, M. Mufakharul. 1995. "The Punjab Land Alienation Act and the Professional Moneylenders." Modern Asian Studies 29(2):271-91.

Jodhka, Surinder Singh. 2000. "Prejudice without Pollution? Scheduled Castes in Contemporary Punjab." Journal of Indian School of Political Economy 12(3-4):381-403. . 2002. "Caste and Untouchability in Rural Punjab." Economic and Political Weekly 37(19):1813-23.

Jones, Kenneth W. 1976. Arya Dharm: Hindu Consciousness in 19th Century Punjab. Berkeley: University of California Press. 
—. 1981. "Religious Identity and the Indian Census." In The Census in British India: New Perspectives, ed. Norman G. Barrier, 73-101. Delhi: Manohar Publishers.

Judge, Paramjit S. 2003. "Hierarchical Differentiation among Dalits.” Economic and Political Weekly 38(28):2990-91.

Juergensmeyer, Mark. 1982. Religion as Social Vision: The Movement against Untouchability in 20th Century Punjab. Berkeley: University of California Press.

Kessinger, Tom G. 1974. Vilyatpur 1848-1968: Social and Economic Change in a North India Village. Berkeley: University of California Press.

Khan, Khan Ahmad Hasan. 1933. Census of India, 1931: Volume XVII, Punjab. Part 1 Report. Lahore: Civil and Military Gazette Press.

Kumar, Aishwary. 2015. Radical Equality: Ambedkar, Gandhi, and the Risk of Democracy. Stanford, Calif.: Stanford University Press.

Marx, KARL. [1843] 1978. "On the Jewish Question.” In The Marx-Engels Reader, ed. Robert C. Tucker, 26-52. 2nd ed. New York: W.W. Norton.

Mayer, Peter. 1993. "Inventing Village Tradition: The Late 19th Century Origins of the North Indian 'Jajmani System.”" Modern Asian Studies 27(2):357-95.

Mazumder, Rajit K. 2003. The Indian Army and the Making of Punjab. New Delhi: Permanent Black.

Middleton, L., and S. M. Jасов. 1922. Census of India, 1921: Punjab and Delhi. Vol. 15, pt. II. Lahore: Civil and Military Gazette Press.

Mufti, AamiR R. 2007. Enlightenment in the Colony: The Jewish Question and the Crisis of Postcolonial Culture. Princeton, N.J.: Princeton University Press.

Narain, Raj. 1932. An Economic Survey of Gijhi, a Village in the Rohtak District of the Punjab. Punjab Village Surveys No. 2. Lahore: Civil and Military Gazette Press.

Nazir, Pervaiz. 2000. "Origins of Debt, Mortgage and Alienation of Land in Early Modern Punjab.” Journal of Peasant Studies 27(3):55-91.

Oвеroi, Harjot. 1994. The Construction of Religious Boundaries: Culture, Identity, and Diversity in the Sikh Tradition. Chicago: University of Chicago Press.

Pandian, M. S. S. 2007. Brahmin and Non-Brahmin: Genealogies of the Tamil Political Present. New Delhi: Permanent Black.

Prakash, Gyan. 1990. Bonded Histories: Genealogies of Labor Servitude in Colonial India. Cambridge: Cambridge University Press.

Prashad, Vijay. 2000. Untouchable Freedom: A Social History of a Dalit Community. New York: Oxford University Press.

Puri, Harish K. 1993. Ghadar Movement: Ideology, Organization, and Strategy. Amritsar: Guru Nanak Dev University Press.

—. 2003. "Scheduled Castes in Sikh Community: A Historical Perspective." Economic and Political Weekly 38(26):2693-2701.

—., ed. 2004. Dalits in Regional Context. Jaipur: Rawat Publishers.

RAHI, RAJINDER, ed. 2011. Sant Ram Udasi: Jeevan ate Samuchi Rachna [Sant Ram Udasi: Life and Collected Works]. Ludhiana: Chetna Parkashan.

RAm, Ronki. 2004. "Untouchability in India with a Difference: Ad Dharm, Dalit Assertion, and Caste Conflicts in Punjab." Asian Survey 44(6):895-912.

2007. "Social Exclusion, Resistance and Deras: Exploring the Myth of Casteless Sikh Society in Punjab.” Economic and Political Weekly 42(40):4066-74.

—. 2008. "Ravidass Deras and Social Protest: Making Sense of Dalit Consciousness in Punjab (India)." Journal of Asian Studies 67(4):1341-64. 
Ramnath, Maia. 2011. Haj to Utopia: How the Ghadar Movement Charted Global Radicalism and Attempted to Overthrow the British Empire. Berkeley: University of California Press.

Rao, Anupama. 2009. The Caste Question: Dalits and the Politics of Modern India. Berkeley: University of California Press.

Rawat, Ramnarayan S. 2011. Reconsidering Untouchability: Chamars and Dalit History in North India. Bloomington: Indiana University Press.

SAndhu, AmandeEP. 2016. "A Growing Movement in Jhaloor Illustrates How Dalit Villagers in Punjab Are Reclaiming Their Right to Panchayat Land.” Caravan, November 29.

Saunders, LesLie S. 1873. Report on the Revised Land Revenue Settlement of the Lahore District in the Lahore Division of the Panjab, 1865-69. Lahore: Central Jail Press.

Scott, James C. 1985. Weapons of the Weak: Everyday Forms of Peasant Resistance. New Haven, Conn.: Yale University Press.

Seth, R. K., and Faiz ILahi. 1938. An Economic Survey of Durrana Langana, a Village in the Multan District of the Punjab. Punjab Village Surveys No. 11. Lahore: Civil and Military Gazette Press.

Singh, RandHir. 1932. An Economic Survey of Kala Gaddi Thamman (Chak 73 G.B), a Village in the Lyallpur District of the Punjab. Punjab Village Surveys No. 4. Lahore: Civil and Military Gazette Press.

Singh, Sardar Gian. 1928. An Economic Survey of Gaggar Bhana, a Village in the Amritsar District of the Punjab. Punjab Village Surveys No. 1. Lahore: Civil and Military Gazette Press.

Skaria, Ajay. 2015. “Ambedkar, Marx and the Buddhist Question.” South Asia: Journal of South Asian Studies 38(3):450-65.

Tandon, Prakash. 1968. Punjabi Century: 1857-1947. Berkeley: University of California Press.

Viswanath, Rupa. 2014. The Pariah Problem: Caste, Religion, and the Social in Modern India. New York: Columbia University Press.

Viswanathan, Gauri. 1988. Outside the Fold: Conversion, Modernity, and Belief. Princeton, N.J.: Princeton University Press. 